\title{
Description of the male of Lepidodexia (Xylocamptopsis) teffeensis (Townsend) (Diptera, Sarcophagidae)
}

\author{
Karlla Patrícia Silva ${ }^{1} \&$ Cátia Antunes de Mello-Patiu ${ }^{1}$
}

\begin{abstract}
'Museu Nacional, Universidade Federal do Rio de Janeiro. Quinta da Boa vista, 20940-040 Rio de Janeiro-RJ, Brasil. karlla-patricia@bol.com.br; camello@acd.ufrj.br
\end{abstract}

\begin{abstract}
Description of the male of Lepidodexia (Xylocamptopsis) teffeensis (Townsend) (Diptera, Sarcophagidae). The male of Lepidodexia (Xylocamptopsis) teffeensis (Townsend, 1927) is described and illustrated for the first time based on material housed in the entomological collection of Museu Nacional, Rio de Janeiro (MNRJ). This monotypic subgenus has been recorded in the Brazilian Amazon Rainforest, first in the state of Amazonas and now in the state of Pará. The general structure of the male terminalia is similar that of other Lepidodexia, especially of the subgenus Lepidodexia, by the short distiphallus, juxta with apical projection, and vesica with a membranous spinous lobe.
\end{abstract}

KEYWORDS. Flesh flies; morphology; taxonomy; terminalia.

RESUMO: Descrição do macho de Lepidodexia (Xylocamptopsis) teffeensis (Townsend, 1927) (Diptera: Sarcophagidae). O macho de Lepidodexia (Xylocamptopsis) teffeensis é descrito e ilustrado pela primeira vez, com base em material depositado na coleção entomológica do Museu Nacional, Rio de Janeiro (MNRJ). Esse subgênero monotípico tem sido registrado na Floresta Amazônica brasileira, primeiramente no estado do Amazonas e agora no Pará. A estrutura geral da terminália masculina é similar a de outras espécies de Lepidodexia, especialmente do subgênero Lepidodexia, pelo distifalo curto, juxta com projeção apical e vesica com lobo membranoso e espinhoso.

PALAVRAS-CHAVE: Moscas da carne; morfologia; taxonomia; terminália.

Lepidodexia (Xylocamptopsis) teffeensis was described by Townsend (1927) in the genus Xylocamptopsis, which he erected for this species, based on one female from Tefé, Amazonas state, Brazil. The holotype was collected on foliage and is deposited at the National Museum of Natural History, Smithsonian Institution (NMNH).

Lopes (1979a) examined the holotype and provided a more detailed redescription. According to the female morphology, the author considered this species closely related to those of Harpagopyga Aldrich, 1916, differing mainly by the presence of setae on abdominal tergite 8 and by the shape of spermathecae. In a study on the tribe Johnsoniini (= genus Lepidodexia sensu Pape 1996), Lopes (1979b) stressed that knowledge of the male morphology was a requirement for deciding about the generic status. Pape (1996) considered Xylocamptopsis a subgenus of Lepidodexia Brauer \& Bergenstamm, 1891, but he still kept it as a separate monotypic taxon because the male remained unknown.

During an ongoing revision of Lepidodexia, a series of five males from Pará state, Brazil, was found in the entomological collection of the Museu Nacional, Rio de Janeiro (MNRJ). These males have a similar morphology to females previously identified by Hugo de Souza Lopes as L. (Xylocamptopsis) teffeensis by comparison with the female holotype, and they also match with regard to the collection data. After a detailed study of this material, we present the first description of the male of $L$. teffeensis, with illustrations of the terminalia.

\section{MATERIAL AND METHODS}

The genital apparatus was prepared following Silva \& Mello-Patiu (2010). A provisory glass slide with glycerol was prepared for observation and drawing using a MOTIC K $400^{\circledR}$ stereomicroscope and a ZEISS M80 ${ }^{\circledR}$ microscope, both with camera lucida. After the illustration, the genitalia were stored in a microvial with glycerol and attached to the pin of the proper specimen. The descriptive terminology follows that of Cumming \& Wood (2009), with some phallic structures following Mello-Patiu \& Pape (2000). Photos were taken with a camera Leica DFC420 in a stereomicroscope Leica MZ16 and software Syncroscopy ${ }^{\circledR}$ Auto-montage.

\section{RESULTS AND DISCUSSION}

Lepidodexia (Xylocamptopsis) teffeensis

(Townsend, 1927)

Xylocamptopsis teffeensis Townsend, 1927. Type locality: Brazil, Amazonas, Tefé. Xylocamptopsis teffeensis; Lopes 1979a: 154-155; 1979b: 926.

Lepidodexia (Xylocamptopsis) teffeensis; Pape 1996: 249.

Male. Length: 7-9 mm ( $\mathrm{n}=5)$ (Fig. 1).

Head. Fronto-orbital plate and parafacial dark brown with slight golden microtomentum, genal groove reddish brown; facial ridge with few short setae near the vibrissa and para- 
facial with a series of fine setulae; gena and postgena dark brown with black setae; frontal vitta and palpus brown; antenna with scape and pedicel yellowish brown, postpedicel with brown apex and yellow base, 1.7 times as long as pedicel, arista long plumose on basal 2/3; 8 frontal setae reaching the base of antenna; proclinate fronto-orbital seta absent, reclinate one present; inner vertical seta longer than frontals; outer vertical seta not differentiate from postocular setae; paravertical setae smaller than inner vertical seta; ocellar setae absent (or poorly differentiate); one pair of postocellar setae with $1 / 2$ of inner vertical seta size (Fig. 2).

Thorax. Brown with slight grey microtomentum and the typical 3 dark stripes (Fig. 1). Chaetotaxy: Acrostichals 0+1; dorsocentrals $2+3$ equidistant; intra-alars $1+2$, supra-alars $1+2$; postalars 2 ; postpronotals 2 ; notopleurals 2 ; proepimeral 1 ; meropleurals 7-8; katepisternals 2; prosternum and proepisternum setose, postalar wall bare. Scutellum with 2 well developed marginal setae, no apical and 1 preapical scutellar setae. Wing hyaline with yellowish veins; $\mathrm{R}_{1}$ bare; $\mathrm{R}_{4+5}$ setulose about $2 / 3$ of $\mathrm{r}-\mathrm{m}$; costal spine not differentiate; cell $\mathrm{r}_{4+5}$ opened; third costal sector bare. Legs brown without microtomentum, pulvilli yellowish; mid femur with 2 preapical posterior setae, 2 median anterior setae, a row of long setae on posteroventral margin, but smaller, spiniform, and with different sizes near the apex (not forming a ctenidium); mid tibia with 2 median posterior, 1 median anteroventral, and 1 median anterior setae.

Abdomen. Brown with pale golden microtomentum and a median longitudinal black stripe along the dorsal surface of the tergites $1+2-5$ (Fig. 1). Tergites $1+2$ with 1 strong lateral marginal seta; tergite 3 with $1-2$ lateral marginals; tergite 4 with a pair of median marginal and 3 lateral marginal setae; tergite 5 with 6-8 marginal setae along the posterior margin; sternites with yellowish margin covered with small black setae sparsely distributed; sternite 5 with a short and almost square base, a long and simple $\mathrm{V}$ median cleft, with setae with similar size along its margin (Fig. 3).

Terminalia. Dark brown with pale golden microtomentum. Cercus with apex brown and with setae sparsely distributed, apex narrower than the base, convergent on posterior view and base (Figs. 4, 5). Surstylus well developed with acuminate apex, presenting a group of setae on posterior margin near the apex; the base rounded and enlarged (Fig. 4). Pregonite elongate with pointed apex and narrow basis, with an acuminate projection in the middle; postgonite similar in size to the pregonite, with a strong median seta (Fig. 4). Phallus with distinct basiphallus

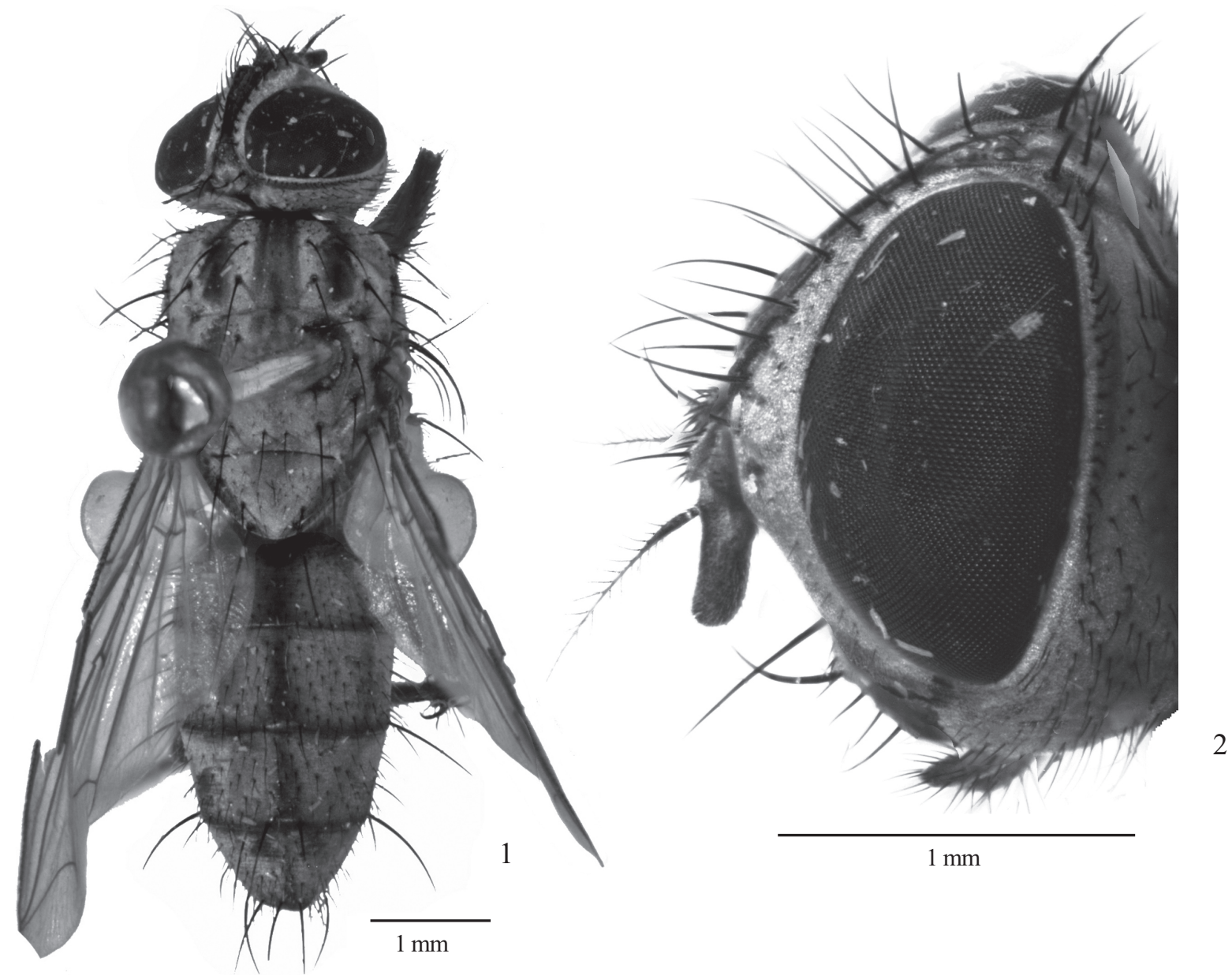

Figs. 1-2. Lepidodexia (Xylocamptopsis) teffeensis (Townsend), male: 1, habitus, dorsal view; 2, head, lateral view. 


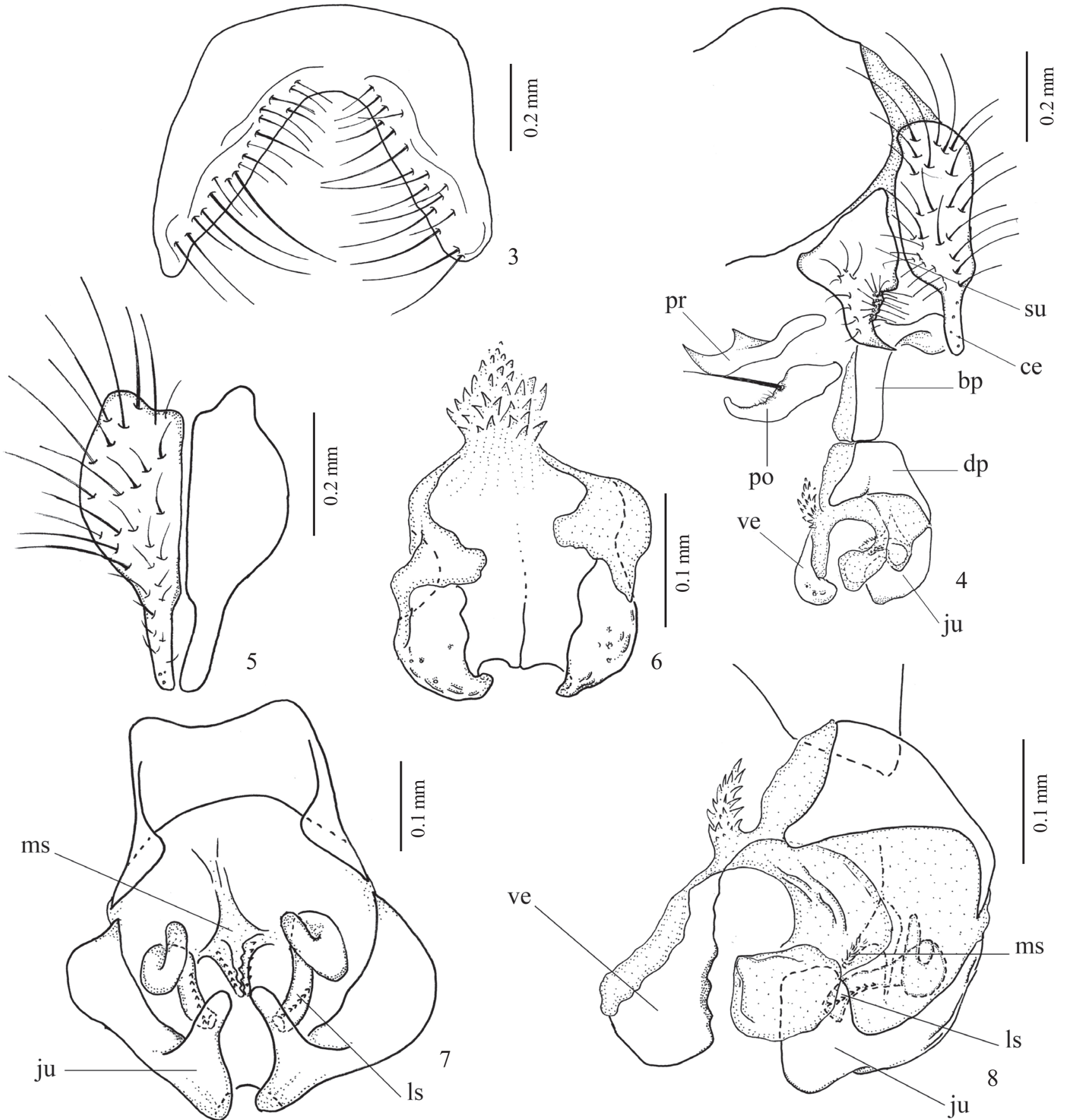

Figs. 3-8. Lepidodexia (Xylocamptopsis) teffeensis (Townsend), male: 3, sternite 5; 4, terminalia, lateral view; 5, cercus, posterior view; 6, vesica, ventral view; 7, distiphallus, ventral view (vesica not represented); 8, distiphallus, lateral view. [Legends: bp, basiphallus; ce, cercus; dp, distiphallus; ju, juxta; 1s, lateral stylus; ms, median stylus; po, postgonite; pe, pregonite; su, surstylus; ve, vesica].

and distiphallus. Distiphallus short with the apex partially membranous (Figs. 7, 8); juxta large and sclerotized, distinctly separated from the distiphallus, showing apical projections bent upwards (Fig. 7); median stylus spinose and flume-like, lateral styli robust and strongly sclerotized with a row of spines at the apex and a coiled base (Figs. 7, 8); vesica with a membranous spinous lobe at the base, a broad membranous proximal area, and a pair of distal sclerotized projections with rounded apex (Figs. 6, 8).
Female. Length: $7-8 \mathrm{~mm}(\mathrm{n}=4)$.

Similar to male, differing as follows: head with 5-6 frontal, 2 proclinate fronto-orbital setae, and ocellar setae slightly smaller than the postocellars. Mid femur with 2 median anterior setae and mid tibia with 1 median posterior seta. Terminalia as in the redescription of Lopes (1979a).

Material examined: BRASIL: Pará, Belém, 2 males, 1 female, 4.VII.1965, H.S. Lopes col.; idem, Instituto Agronômico do Norte, 2 males, 
2 females, 25/30.X.1959, E. Lobato col.; idem, Murucutum, Fazenda Velha, 1 female, X.1959, D. Lacombe, E. Lobato, J. Evangelista col.; Pará, Abaeté [Abaetetuba], 1 male, 10.XII.1936, G. Deane col.

\section{DISCUSSION}

Male terminalia of $L$. $(X$.) teffeensis is very similar to those of other species of the subgenus Lepidodexia by the short distiphallus, juxta with apical projection, and vesica with a membranous spinous lobe. Among them, L. (L.) grisea (Lopes, 1951) is most similar by the morphology of terminalia and general coloration of abdomen, and it also matches the Amazon distribution. However, L. (L.) grisea may be distinguished by the presence of ocellar and apical scutellar setae, sub-primary notopleurals, cushion-like formations along the inner margin of sternite 5 , and the shape of vesica, median and lateral styli. Besides, the distal part of the surstylus of $L$. $(X$.$) teffeensis is very characteristic.$

In the current arrangement of Lepidodexia, 32 subgenera are recognized and they show great similarity in the phallus, although a marked disparity in the external morphology. Therefore, some authors have pointed out the need for a comprehensive revision of the genus in order to verify whether this arrangement constitutes a monophyletic group (Pape 1996; Giroux et al. 2010). Therefore, this contribution on the subgenus Xylocamptopsis is part of a more comprehensive study that focuses on the morphological cladistic analysis of Lepidodexia, which is the Ph.D. thesis subject of the first author and is still in progress. At last, the male description of L. (X.) teffeensis will allow us to include it in the analysis and recover its relationships within Lepidodexia, to then deciding its systematics placement, whether included in Lepidodexia, or in Harpagopyga, or remain as a distinct monophyletic taxon.

\section{ACKNOWLEDGEMENTS}

To CAPES (Coordenação de Aperfeiçoamento de Pessoal de Nível Superior) for the doctoral fellowship (KPS) and to $\mathrm{CNPq}$ (Conselho Nacional de Desenvolvimento Científico e Tecnológico) for the postdoctoral fellowship (CAMP, Proc. 151126/2009-7).

\section{REFERENCES}

Cumming, M. J. \& D. M. Wood. 2009. Adult morphology and terminology, p. 9-50. In: B. V. Brown, A. Borkent, J. M. Cumming, D. M. Wood, N. E. Woodley and M. Zumbado, Manual of Central American Diptera. Vol. 1. Ottawa, NRC Research Press, $x i+714$ p.

Giroux, M.; T. Pape \& T. A. Wheeler. 2010. Towards a phylogeny of the flesh flies (Diptera: Sarcophagidae): Morphology and phylogenetic implications of the acrophallus in the subfamily Sarcophaginae. Zoological Journal of the Linnean Society 158: 740-658.

Lopes, H. de S. 1951. Sôbre o gênero Lepidodexia Brauer \& Bergenstamm, 1891 (Diptera-Sarcophagidae). Memórias do Instituto Oswaldo Cruz 49: 641-658.

Lopes, H. de S. 1979a. Redescription of the holotypes of some Neotropical Sarcophagidae (Diptera) described by C. H. T. Townsend. The Canadian Entomologist 111: 149-160.

Lopes, H. de S. 1979b. Contribution to the knowledge of the Tribe Johnsoniini (Diptera, Sarcophagidae). Revista Brasileira de Biologia 39: 919-942.

Pape, T. 1996. Catalogue of Sarcophagidae of the World (Insecta, Diptera). Memoirs on Entomology, International 8: 1-558.

Mello-Patiu, C. A. \& T. Pape. 2000. Definitions of Dexosarcophaga Townsend, 1917 and Sarcofartiopsis Hall, 1933, incluing two new species and redescriptions of Sarcofartiopsis cuneata (Townsend, 1935) (Diptera, Sarcophagidae). Boletin de Entomología Venezolana 15: 181-194.

Silva, K. P. \& C.A. Mello-Patiu. 2010. New species of Dexosarcophaga Townsend from Panama with an illustrated key to species of the subgenus Bezzisca (Diptera: Sarcophagidae). Journal of Natural History 44: 89-106.

Townsend, C. H. T. 1927. Synopse dos generos muscoideos da região humida tropical da America, com generos e especies novas. Revista do Museu Paulista 15: 205-385.

Received 2/12/2010; accepted 2/12/2011

Editor: Silvio Shigueo Nihei 